\title{
Methodology of Integrated Coastal Zone Management Plan Preparation-Case Study of Andaman Islands, India
}

\author{
Devaraj Asir Ramesh ${ }^{1}$, Arumugam Senthil Vel ${ }^{2}$ \\ ${ }^{1}$ Training Officer, Society of Integrated Coastal Management, Ministry of Environment and Forests, Government of India, New \\ Delhi, India; ${ }^{2}$ Director, Society of Integrated Coastal Management, Ministry of Environment and Forests, Government of India, New \\ Delhi, India. \\ Email: asiramesh@yahoo.com
}

Received January $1^{\text {st }}, 2011$; revised April 28 ${ }^{\text {th }}, 2011$; accepted June $14^{\text {th }}, 2011$.

\begin{abstract}
Generally, approaches of coastal issues are sectoral basis and solutions have been formed in adhoc fashions which are not long lasting. Integrated Coastal Zone Management (ICZM) is conceived as a holistic management tool working across sectoral, disciplinary, and institutional boundaries. ICZM planning is a continuous process to achieve the goals and objectives by using alternative decisions. ICZM plan is providing boundary conditions for limitation, negotiation and implementation. Planning for coastal management is essentially requires integration of resources, uses, issues, and tools for achieving the management objectives. The ultimate goal of ICZM is to improve the quality of life of human communities. Coastal area management needs integrated, interdisciplinary and multi-sectoral approaches for sustainable utilization of resources, which is the fundamental objective of the resource planners and managers. Methodology for ICZM planning is differing in relation to the regional culture, society, economics, politics, nature, technology, scientific, human behavior, etc. Planning for coastal management is very easy by following the methodology or framework developed for the planning process. A case study of ICZM Plan for Andaman has been prepared by using the participatory methodology, which is the source of consensus for all stakeholders of the Andaman Islands. The tasks of ICZM Plan preparation for Andaman Islands includes, knowledgebase development, selection of ICZM plan preparation methodologies, conflict identification, risk analysis, cost benefit analysis, strategic and action plans, recommendations and institutional changes. This ICZM methodology could be used for comparing and understanding the boundary conditions of union or federal developing nations towards comparative planning.
\end{abstract}

Keywords: ICZM, Methodology, Database, Planning, Strategy, Andaman

\section{Need of ICZM}

The coastal areas are assuming greater importance in recent years, owing to increasing human population, urbanization and accelerated developmental activities. These anthropogenic activities have put tremendous pressure on the fragile coastal environment. In all the coastal states of India, coastal zone management has got growing importance. The reasons for this are several: the density of people residing in the coastal zone is high and increasing and conflicts between coastal communities are obvious. Conflicts among user-groups competing for space are becoming more and more common [1]. The Coastal Zone is strategically important from environmental, economic and societal points-of-view. Therefore, solving or miti- gating some of its problems is of vital consideration when shaping policy for sustainable development, and needs integrated and co-ordinated management policies [2].

Generally approach of coastal issues on a sectoral basis and solutions are formed in an adhoc fashion and inventories are not long lasting. Integration of knowledge, skills and information etc., at different levels within the administration and different stakeholders are neglected. The problem in policy coordination is a standard and recognized one in developed and developing countries. In all cases, where government is organized in sectoral ministries there is difficulty in coordinating issues. Hence, it could be argued that there is also a need for structural reforms if there is to be capacity for ICZM as a sustainable development tool. Integrated coastal management (ICZM) 
is conceived as a holistic management tool working across sectoral, disciplinary, and institutional boundaries [3]. The key challenge for ICZM is lack of integrated coastal policies and effective implementation, due largely to the difficulty of coordinating among several government agencies responsible for managing coastal activities [4]. Collaborative and integrated approach for decision making is required to secure the sustainable development of marine areas in a healthy environment [5]. ICZM has been practiced in both developed and developing countries for decades [6].

There are large numbers of researches and contributions for the development of ICZM plan for coastal zone towards sustainable development. However, resource managers are facing pressure to act positively in establishing measures that will maintain sustainable development of the environment [7]. Many marine ecosystems have faced some degree of exploitation and any data compiled from them reflects a degree of alteration from human impacts, it is however important to establish current levels of diversity as a starting point for future management plans. Sustainability has been given consequence by national governments through institutional reform [8]. Identification of major interactions between CZM components and their dynamics allows the type of problem(s) to be assessed in conjunction with their impacts on stakeholders. Understanding the scale of influence of components of system and risk associated to changes taking place form important considerations to the solution formulation process. Identification of a preferred solution is made from consideration of all the alternative solutions and balances the possible outcomes of each solution against three objectives: sustainable development, minimizing risk to people and property, and minimizing the cost of sustainable development [9].

ICZM is a continuous and dynamic process that unites governments and the communities, science and management, sectoral and public interests for developing and implementing an integrated plan. The ultimate goal of ICZM is to improve the quality of life of human communities. Coastal area management needs an integrated, interdisciplinary and multisectoral approaches for sustainable utilisation of resources, which is the fundamental objective of the resource planners and managers. ICZM practices can enhance the nature's contribution to human welfare and preventing undesirable effects. ICZM can suggest suitable legislations, strategies and policies to the managers for conserving and managing the natural resources. ICZM can minimise the costs and costly delays in project implementation; minimise the losses to the various users; minimise damage to the marine environment; make the most efficient use of infrastructure and avoids conflicting use of coastal and marine environment. Successful
ICZM depends on effective participation of government agencies, Non GovernmentalOrganisations (NGO's), and all institutions of the society.

The tasks of ICZM plan preparation for Andaman Islands initiated by Government of India by conduction of case study in Andaman Islands to prepare an ICZM plan. The ICZM plan process of the Andamansincludes, database and knowledgebase development, framework of methodology, conflict identification, risk analysis, alternative opportunities, cost benefit analysis, strategic and action plans, and recommendations of institutional changes etc. ICZM plan has been prepared and submitted to Government of India. This manuscript describes the background of methodology of preparation of ICZM plan in Andaman Islands of Government of India.

\section{ICZM Plan and Requirements}

Coastal zone management has been practiced from 1960's as a managerial activity implemented through its regional, national, and sub-national programs [10]. ICZM has become the standard approach to coastal planning and management throughout the world. Planning is the important consequence of ICZM. ICZM cannot be implemented unless clear planning processes with opportunities for community input are designated. Development and implementation of ICZM plan combines; 1) establishment of an overall policy for the sustainable development of the coastal zone, 2) formulation of sectoral development policies and plans that are compatible with the objectives of the overall policy, 3) integration of sectoral plans into statewide development plan and 4) coordination of development initiatives at the state, district and local levels. A key principle that should also be adopted is the optimisation of long-term productivity of resources. This requires greater cooperation among different sectors and levels of government, adjustment to legislation and improvement of basic management skills. An institutional, organizational, legal, and financial framework is required for an integrated approach to materialize the management objectives. Creation of an enabling environment is a precondition for successful cooperation among different organizations for execution of multi-sector projects. The participating organizations or the stakeholders must have full control over the management of all aspects of their components, leaving only central coordination to the lead agency for participatory management planning [11].

ICZM plan process provides opportunities to find out the local communities needs and initiate participation in natural resource management. The key to comprehensive participation is not only to ensure public participation through consultation but also to have community representatives sitting directly on the decision-making bodies [12]. The planning model provides an essential first step 
in integrated management. There is no universal design for a marine-integrated management system. Different regions will have different suites of human activities drawing on different ecosystems on different scales [13].

\section{Andaman Islands-Significance of ICZM Planning}

The Andaman and Nicobar Islands comprise about 306 Islands of volcanic origin situated on a submerged mountainous hill range arching from ArakanYoma in Burma in the north and Sumatra in the south between $6^{\circ}$ to $14^{\circ} \mathrm{N}$ Lat and $92^{\circ}$ to $94^{\circ} \mathrm{E}$ Long, occupying an area of about $8249 \mathrm{sq} \cdot \mathrm{km}$ in Bay of Bengal. The origin of the islands is believed to be from a single eruption, tentatively dated on late Pliocene period [14]. The coastline is about 1962 $\mathrm{km}$ long, which is highly irregular. Total length of the islands from north to south is $700 \mathrm{kms}$. The highest elevation of the island is Saddle Peak in North Andaman, which is elevated 732 meters above the sea level. Being oceanic islands, the continental shelf areas along these islands are limited to about $16,000 \mathrm{sq} \cdot \mathrm{km}$. The island have a tropical climate and the temperature ranges from $18^{\circ} \mathrm{C}$ to $34^{\circ} \mathrm{C}$. The islands receive precipitation during both southeast and northwest monsoons, which together amount for 9 to 10 months/year and the annual rainfall in this area is $3180 \mathrm{~mm}$. Of the total islands only 38 Islands are inhabited, 11 in the Andaman group and rest in the Nicobar group. Number of named Island is 188 and un-named are 118; the number of named rocks in this island groups are 61 and the un-named rocks are 205 [15].

Primary production in Andaman and Nicobar coastal waters are ranging between $0.07 \mathrm{~g} \mathrm{C} / \mathrm{sq} \cdot \mathrm{m} / \mathrm{day}$. All the islands have variety of terrestrial ecosystems and fringed by mangroves, coral reefs, and sea-grass and seaweed ecosystem in the coastal and marine areas. The Exclusive Economic Zone (EEZ) (0.6 million mk2) of the island extending upto 200 nautical miles from the shoreline is 75 times larger than the islands. The flora of Andaman is predominately resembled with that of Burma and the Nicobar is resembling with Sumatra and Malaysia [16]. Dense forest covered $76 \%$ of the islands, $1.5 \%$ were open forests and $12 \%$ of the geographical area are mangroves. Forest type ranged from the giant evergreen to tropical evergreen moist, deciduous and littoral forests. Forests occupy $7606 \mathrm{~km}^{2}$ (92.2\%) of the total geographical area, of this Andaman and Nicobar group of Islands possessing $5883 \mathrm{~km}^{2}$ and $1723 \mathrm{~km}^{2}$ respectively. Of the total forest cover, dense forests, open forest and mangroves constitutes $40 \%$, 40\% and $12.7 \%$ respectively [17]. Legal forest area is $7170.69 \mathrm{~km}^{2}$, which constitutes $86.93 \%$ of the geographic area of these Islands. Out of this, 4242 $\mathrm{km}^{2}$ are protected forests and $2929 \mathrm{~km}^{2}$ are reserved for- ests [18].

The Islands are the third most significant area for biodiversity in India. Andaman and Nicobar Islands are rich in endemic species because of their long isolation from the adjoining landmass. In total about 10,159 species of fauna and flora have been recorded from this island group, of this 856 are endemic to this islands [18]. Coral reefs of Andaman and Nicobar are the second biodiversity rich zone found in the world. Coral reef surrounded in this islands are about 11,939 sq·kms, possessing 197 coral species and $80 \%$ of coral diversity [19]. Mangrove distribution in this island groups are about $1011 \mathrm{sq} \cdot \mathrm{kms}$ in Andaman Islands and $37 \mathrm{sq} \cdot \mathrm{km}$ in the Nicobar islands [20]. The estimated fishery potential available in the coastal waters are 160,000 tons, of which tuna and tuna like fishes comprises about 1,00,000 tons. Of the total fish stock of this region only 13,200 tons have been harvested. Tourism sector presently shares $2.03 \%$ turnover of the Andaman and Nicobar Union territory. Based on the Andaman Tourism Department report, the tourist arrival to the island was found to have increased by $776 \%$ for domestic tourists and 321\% for international tourists in 18 years period [17].

Andaman and Nicobar Islands are opened for penal settlement during 1857 . The activities of the early settlers were confined to some area around Port Blair. Due to the biological richness and conservation importance in the Islands, 94 sanctuaries, and 9 national parks have been established. Total human population of the island is 356,265. Andaman and Nicobar Islands have six varieties of indigenous people and tribal reserve area is 3265.87 $\mathrm{km}^{2}$. About $60 \%$ populations of the settlers are engaged in agriculture and allied activities. Of the available revenue land, only $21 \%$ is under intense cultivation, another $11 \%$ is classified as fallow and cultivable waste (land that is cultivable, but currently lies fallow). Plantation crops cover $45 \%$ of the revenue land. Licenced fishermen number in this island group is around 2,524 and they ply 1,983 craft on the sea. The gross domestic product GDP of the island has increased from Rs. 532.9 million (Years. 1980-1981) to 5,152.3 million (Years. 1996-1997) [21].

About 223,937 $\mathrm{m}^{3}$ of sand was officially quarried from the allotted 72 beaches of the island during between 1998 and 2001 to meet out the demand of construction materials which influence over the coral population. These areas are designated as one among the India's bioregion, and have a variety of coastal ecosystems. Government of India has classified this area as "Class A", "No Industrial Zone”. This policy protects the environment from largescale industries, polluting the environment of Andaman and Nicobar Islands. Tourist arrival to the island is increasing year by year hence, Department of Environment and Forests, and Department of Tourism, of Andaman 
and Nicobar Islands are interested in utilizing the resources. The departments of the island have various developmental plans related to the tourist attraction to the island. Department of Tourism is interested in high value tourism and the Department of Environment is interested in low value tourism. But, both departments are focusing on coastal tourism, which require CRZ relaxation from most of the areas and relaxation from forest and wild life Acts of Government of India. Fishery resources are under exploited in this island due to lack of man power involved in fishing sector. Aquaculture and mariculture development activities have significant potentials in this island and the fishery department is ready to assist through techniques, subsidies and incentives. Marketing of capture fisheries is the limitation for intensive coastal fishing and deep-sea fishing. Public Welfares such as transport, communication, drinking water, water storage, health and sanitation, education are important sectoral areas require developmental plans.

Islands of Andaman are rich in natural resources, which have national conservation interest and importance in relation to forestry, wild life, bioactive components, marine flora and fauna, tourism, fishery, etc. The island natural resources are phasing threats due to the increase (4\%/annum) of population and over harvest of natural resources. Inhabited population of the islands is totally dependent on the forest area and its resources. Since the demand has been increased by the population pressure, supply of natural resources are stagnant or limited by government actions through legislations which leading to violations and conflicts over various sectors of the community. Illegal resource exploitation such as sand mining, forest felling, and habitat alteration are the major threats to the sustainability of the resources in this Islands. Poaching, human animal conflicts, tourism and inappropriate management practices are the important consequences due to human pressure. Government is initiating various developmental and conservation projects, the rate of benefits that, and reach to the focuss group is very meagre. Most of the natural resources in this island are under exploited, and few of them are over-exploited Integrated Coastal Zone Management (ICZM) Plan preparation is getting great significance.

The fundamental purpose of all coastal management initiatives is to maintain, restore, or improve specified qualities of coastal ecosystems and their associated human societies [3]. All the Government Departments of Andaman and Nicobar islands have sectoral plans, but they are not integrated with the other segments. The present ICZM Plan has success in integrating the activities of the departments. One dimension of integration is integration among different levels of government. This typically requires national mandates for ICZM and incentives that encourage appropriate action at lower levels in the governance hierarchy [22]. Benefits of ICZM is relevant to the plan area such as development of economic and environmental quality management programs and plans, integration of sectoral policies (fisheries, tourism, energy, transport, agriculture, natural risks, waste disposal, etc.), integration of different levels of government, from local to international, integration of all interest groups into the management process, integration of all management tools (the drawing up of plans, their implementation and evaluation), integration of different disciplines (legal, ecological, geo-morphological, economic and social aspects, among others), integration of the administration's resources in all the departments involved [23].

The Leutinon Governor (LG) governs the Islands with the help of a Secretariat headed by a Chief Secretary. The secretaries of the department's head over the programs and policies with relate to the sectors. An elected Member of Parliament is representing the Andaman and Nicobar Islands in the lower house of Parliament (LokSabha). The lowest administrative tier is composed of the Gram Panchayat at the village level. Above them is the Panchay at Samiti, which represents a group of villages. The highest tier is the Zilla Parishad or District Council, and is made up of members elected at the district level.

\section{ICZM Planning Framework}

In general planning processes requires a framework methodology to include, consider, evaluate and reject the composition of resources, uses, issues and draft plan preparation for ICZM. ICZM Plan preparations for Andaman Islands have the following process in developing the planning methodology. Define the Problem $\rightarrow$ Staffing $\rightarrow$ Data collection and storage $\rightarrow$ Development of knowledgebase $\rightarrow$ Cost benefit analysis $\rightarrow$ Risk analysis $\rightarrow$ Draft strategic plan preparation including decisions $\rightarrow$ Workshop for managers and executives of the area $\rightarrow$ Report modifications $\rightarrow$ Public hearing on ICZM report $\rightarrow$ Recommended ICZM plan. Methodology of planning framework is described in Chart 1.

\section{Data Collection and Knowledgebase}

Integrated Coastal Zone Management (ICZM) requires accurate and replicable scientific data sets which can be used as a basis for informed decision making [24]. The planners need all kind of reliable data for synthesizing and justifying his ideas developed for every aspects or sectors. The decision makers and policy planners need data and tools to monitor and assess natural resource inventories, environmental change, and social change for sustainable development [25]. Satellite remote sensing techniques can routinely observe the coastal area and provide information about conditions and changes over 


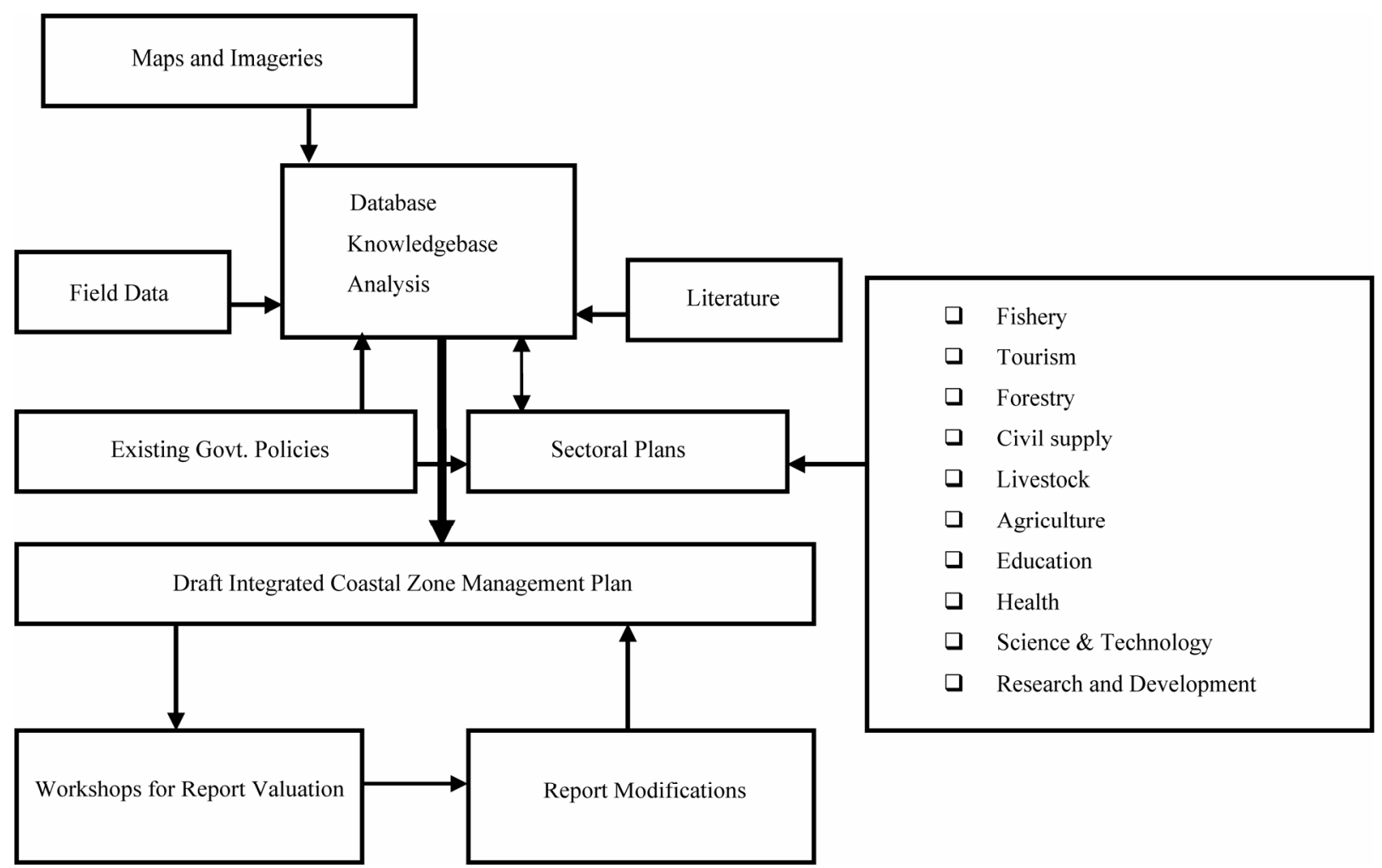

Chart 1. Methodology for ICZM plan preparation of andaman islands.

time. It has long been recognized that remote sensing is one of the most important approaches to the coastal problems, the other being in situ measurement programs and modeling studies. Coastal environmental change monitoring in China is particularly focused on the river deltas and coastlines. Remote sensing has been an important component of those monitoring systems [26].

Science and practical ecological, social, and cultural knowledge may combined be able to fill in most of the data needs of ICZM plan preparation. Microlevel issues and their data shall be kept outside from the main ICZM database. Because, database could suffer by information overload and form a pile of junk data. More information is therefore not always better, if it is neither processed nor put to use [27]. Data are the raw material from which information is produced. Information is a collection of data relevant to a recipient at a given point in time. Information is data in context: it has meaning, relevance and purpose. An important consequence of this definition is that information is seen as one element of a hierarchy through which sustainable management of the coast may be achieved, thus: Data + Context = Information, Information + Analysis = Understanding, Understanding + Management $=$ Possibility of sustainable action [28]. Database development and information sharing is viewed as an important way to improve the state of the coastal areas [29]. Hardly any problem in the coastal zone is delimited by academic disciplines, coastal zone managers must tap on insights of multiple disciplines, as well as from informal, local sources of knowledge [30]. For the NOAA restoration center project, internet web sites of partner organizations, phone interviews with project managers, USGS maps, and progress reports for the projects were used for collection of data [31].

Although the grant and allocations for Andaman and Nicobar islands are comparatively higher than the mainland states of India, the scientific activities and documentation were not sufficient to develop an ICZM plan. Available natural resources data for Andaman Islands were mostly qualitative, but ICZM plan requires site specific, thematic and time scale data. Primary and secondary data of Andman Islands were collected for ICZM plan preparation by 1) census and sampling methods, 2) investigator and mail enquiries, 3) registration and 4) information from correspondence, 5) remote sensing data. The sources of secondary data are published materials usually 1) offcial publications of the central and state governments, 2) reports and official publications of international bodies, 3) private publications, 4) publications, 5) remote sensing data brought out by the research people or scientists, universities, etc. All kind of historic data such as maps, texts, video clipping, ques- 
tionnaires, audiotapes etc., were collected to develop an ICZM database. Data available in library, individuals, departments, newspapers, journals, textbooks, etc., were collected and compiled for easy retrieval and evaluation. The data were verified for its quality, relevance and consistency toavoid duplications or replications. The compiled data were computerized by developing a RDBMS database. Oracle is the suitable Relational Database Management System (RDBMS) experienced for ICZM plan process.

The Andaman Islands database contains the parameters such as physical, chemical, revenue areas, island morphology, geology and geomorphology, mechanical analysis of sediment, island and global warming, resources, population, settlements, agriculture, civil supply, secondary group, family, marriage institutions, economic status, tourism, fishing, livestock, housing, technology and development, communication and transport, industries, heritage sites, near-shoreloffshore structures, education and curriculum, health and sanitation, disaster and mitigation, social control and security, legal control, local administration, NGO's of the area, and research and development. In general the data-outputs are numerical, text and maps.

Models were prepared for population growth, forecast of land conversion, suitable roads, water storage structures, suitable agriculture sites, sand deposition etc., towards better or alternative management option or plans. Matrixes were developed for identification of cross sectoral interactions, which has used for demonstrating the interactions at all knowledge levels. Matrix can be interactive in that the impact of new changes (management interventions) can be feed back into the matrix to determine subsequent secondary-level changes and whether they either produce or remove impacts upon stakeholders [32]. Environmental Impact Assessments (EIA) were conducted for ICZM plan for Andaman Islands to find the rate of impact or influence over the other sectors, if the activity will implemented. Impact predictions contained in Environmental Impact Statement's (EIS's) the main output of the EIA process are taken into account by the decision-making body when determining the application for development consent [33].

Knowledgebase provides insight about the history and trend, which is essential for predicting and forecasting the issues and factors for the planners. Models have grown more sophisticated and better able to handle environmental dynamics at the regional and even local scale [34]. In general models were built for explaining, predicting and supporting the plans, strategies and policies. Sometimes the models, which were applied for insufficient or inadequate time series data lead to wrong judgment and failure. The models could not provide definite answers to all clarifications required by ICZM practitioners, but act as a reminder of some of the principles that need to be considered and interactions that might occur.

\section{Cost Benefit Analysis and Risk Analysis}

When developing plans and especially in-relation to hard engineering options such as seawall construction, harbor construction, pipelines, dredging, resort development kind of activities etc., cost benefit analysis have been accomplished. Cost benefit analysis is widely used for all kind of developmental plans because of its flexibility and broad applicability to analyze the costs and benefits of a range of interacting environmental, social and economic impacts. Cost benefit analysis and risk analysis have been made for Andaman Islands to draft decisions. It has proved its applicability for comparing the present values of benefits with the opportunity costs.

Risk is pervasive at all stages of Andaman ICZM planning, and risk management is a key objective of ICZM it is not a simple concept to incorporate for two main reasons. Firstly risk is difficult to measure scientifically; secondly, risk perception by individuals and communities is ingrained within the functioning and cultural values of their society and may not entirely confer with a scientific assessment of risk. However, the risk evaluation matrix can be used to support the assessment of management options. The matrix divides risk into the probability of the hazard and the impact of hazard (i.e. the scope of elements at risk and their vulnerability to hazard). The matrixes were used to demonstrate the selected management options in the workshops to justify the comparative risk of the alternative options followed by [32].

\section{Draft Plan Preparation}

All the Government Departments of Andaman and Nicobar islands have sectoral plans, but they are not integrated with the other sectors/departments. To integrate the sectoral plans, interactive sessions such as workshops and meetings were conducted. Draft integrated plans were prepared, which contains information about plan area, status of the island, issues and benefits of the island, recommended strategies, alternative justification of the strategies, recommended developmental plan or action plan for the sectors and implementation mechanism. The draft plan was critically evaluated by the experts working in the ICZM subject.

To strengthen the ideas, experts from various sectors were invited to contribute to the plan. The draft plan is prepared using simple and general statements for easy understanding to all kind of readers. Maps and color graphs were presented for easy access of information. The draft plan was circulated to all coastal managers and academicians for improving the structure and modifica- 
tion, prior to submission to the primary and secondary stakeholders. Local authorities consensus have been arrived, which was the important milestone for ICZM plan development process. Local authorities can play in implementing sustainable development is because much of the emphasis within policy statements is placed upon the local scale as the most relevant for action [35].

\section{Workshop for Evaluation of the Plan}

The draft ICZM plan was circulated to executives, management departments, primary and secoundary stakeholders of Andaman and Nicobar islands to evaluate the application significance of the recommended plan. Twenty five departments such as Andaman and Nicobar Secretariat, Department of Environment, Department of Tourism, Department of Fisheries, Department of Industries, Department of Agriculture, Andaman and Nicobar Developmental Corporation (ANIDCO), Deputy Commissioner, Port Management Board, Department of Education, Department of Health, Department of Rural Development, Department of Animal Husbandry, Department of Ocean Development, etc., were invited to express their views of the plan. "Workshop on Evaluation of the Draft Report" was conducted to extract their views and the required modifications of the plan. Since they were aware about the draft plan by the advance receipt of the draft copy, their recommendations and suggestions were considered for modifications. The information arrived from the workshop discussions were evaluated and the modified pages sent to the local administrative bodies of Andaman and Nicobar islands.

Thus, coastal stakeholders encouraged to involve themselves in the decision-making process and to contribute their knowledge to participatory research. Such interactions were responding to the experiences and needs of the community, fostering collaboration between researchers and community in research activities, and promoting common knowledge and raising awareness among community members [36]. Interaction must occur at every stage, from the scoping process to strategy or plan development to implementation. The form of interaction will vary at different phases, involving stakeholders throughout the process is important because power manifests itself during each phase. Sharing this power not only helps address the complexity of issues and reveals new options, but it also makes them more viable and supported [37].

\section{Public Hearing of the Plan}

Public hearing is an important role in the total development process for an active and dynamic public participation in ICZM plan development of the Andaman. It is an integral part of planning process to make people free to express their needs and encourage their participation in ICZM plan process. The participatory planning has helped community based management or ecosystem management at decentralized management and governing system of the coastal resources. It is not only provides information to the public but, also create awareness among them. The ICZM plan of Andaman was distributed to the mass medias to broadcast the views of the draft plan. Best coastal practices should be reviewed and shared among coastal managers, to promote integration of natural and social scientific knowledge with local knowledge in the formulation and implementation of integrated coastal management plans [29]. Resource users and other coastal stakeholders must be encouraged to involve themselves in the decision-making process and to contribute their knowledge to participatory research. Such research consists of three key elements: responding to the experiences and needs of the community, fostering collaboration between researchers and community in research activities, and promoting common knowledge and raising awareness among community members [36]. The lack of interaction between administrative and sectoral layers cannot be overcome by technology alone, but by tighter coupling and an ongoing dialogue between the research community and those with practical responsibilities for the coast [38].

\section{Indicative Plan Output}

Establishing ICZMP strategies on small islands has the positive thinking of starting a process, initiate dialogue, stress the need for a new style of governance, improve public participation on decision making, raise awareness for coastal problems, etc. The increase demand for regulations and decision support is producing a "boom" of plans and strategies at different scales and levels [39]. The aim of planning is to adopt rationale methods for social/institutional needs or demand of Andaman Islands. Hence, ICZM plan for Andaman has been expected as the remedy to all socio-economic ills. The ICZM plan process has helped to identify the resources and supply chain of scarce products. Planning process also indicated distribution of resources and time frame use limits by strategies. In Andaman ICZM planning, "strategies" have been referred as the methods used in formulating a development plan. As like Government of India, Andaman ICZM plans does not have single strategy to achieve sustainable development. Planning in India is mixture of balanced and unbalanced growth techniques. The overall strategy in Indias' planning has been one of the balanced developments of the economy. India's five-year plans are attempting to develop balanced economy in order to achieve the balanced growth by priorities certain sectors in each plan. Even if spatialplanning is the best instrument 
to address coastal problems in small islands, ICZM strategies are needed, at least aiming at it, and pavethe path to achieve it [38].

Recommended strategies developed for adopting decisions in environmental governance and forest have been discussed here to familiriaze the output of ICZM planning for sustainable development. The recommended strategies for environmental governance are;

1) Natural resources of the inhabited islands should be protected.

2) Encourage developmental activities in inhabited islands.

3) Relax the statutes, towards development in the inhabited island.

4) Apply participatory management technique.

To achieve the above strategies, the following decisions have been recommended for activities on the natural resources.

\begin{tabular}{|c|c|c|c|c|c|c|c|}
\hline \multirow{2}{*}{ Natural resource } & \multicolumn{7}{|c|}{ Activities } \\
\hline & Tourism & Fisheries & Agriculture & $\begin{array}{l}\text { Aquaculture/ } \\
\text { Mariculture }\end{array}$ & $\begin{array}{l}\text { Jetties/ } \\
\text { Harbor }\end{array}$ & $\begin{array}{c}\text { Energy } \\
\text { producti }\end{array}$ & $\begin{array}{l}\text { Water } \\
\text { harvest }\end{array}$ \\
\hline Forest & $\mathrm{L}$ & $\mathrm{R}$ & $\mathrm{R}$ & $\mathrm{R}$ & & E & E \\
\hline Surface water & E & E & & E & E & E & \\
\hline Streams & $\mathrm{L}$ & $\mathrm{L}$ & E & & E & E & E \\
\hline Coral reef & $\mathrm{E}$ & $\mathrm{L}$ & & $\mathrm{R}$ & $\mathrm{R}$ & $\mathrm{R}$ & \\
\hline Mangroves & E & E & & $\mathrm{R}$ & $\mathrm{R}$ & $\mathrm{R}$ & $\mathrm{R}$ \\
\hline Beaches & $\mathrm{E}$ & & & & $\mathrm{L}$ & $\mathrm{L}$ & \\
\hline Tribe & $\mathrm{R}$ & & & & & & \\
\hline Fauna \& Flora & $\mathrm{R}$ & E & E & E & & & \\
\hline
\end{tabular}

L = Limit, $\mathrm{R}=$ Restrict, $\mathrm{E}=$ Encourage, $\mathrm{X}$ = Relax.

The recommended strategies for forests management are;

1) Adopt flexible protection policy in the inhabited islands.

2) Regulate and relax the coastal investments.

3) Encourage human welfare structures in the inhab- ited islands.

4) Encourage harvest of economically viable forest products in the inhabited islands.

5) Increase awareness and education camps.

To achieve the above strategies, the following decisions have been recommended;

\begin{tabular}{|c|c|c|c|c|c|c|c|c|}
\hline \multirow{2}{*}{ Forest control } & \multicolumn{8}{|c|}{ Activities } \\
\hline & Tourism & Fisheries & Agriculture & $\begin{array}{l}\text { Aqua/mari } \\
\text { culture }\end{array}$ & $\begin{array}{c}\text { Jetties/ } \\
\text { Harbour }\end{array}$ & $\begin{array}{c}\text { Energy } \\
\text { production }\end{array}$ & $\begin{array}{c}\text { Water } \\
\text { harvest }\end{array}$ & $\begin{array}{l}\text { Harvest forest } \\
\text { products }\end{array}$ \\
\hline Reserve Forest & $\mathrm{L}$ & $\mathrm{L}$ & $\mathrm{L}$ & $\mathrm{R}$ & $\mathrm{R}$ & E & $\mathrm{E}$ & E \\
\hline Sanctuaries & $\mathrm{L}$ & $\mathrm{L}$ & $\mathrm{L}$ & $\mathrm{R}$ & $\mathrm{R}$ & $\mathrm{E}$ & $\mathrm{E}$ & E \\
\hline Coastal Regulation Zone & $\mathrm{X}$ & $\mathrm{X}$ & & $\mathrm{X}$ & $\mathrm{X}$ & $\mathrm{X}$ & $\mathrm{X}$ & E \\
\hline Forest Act & $\mathrm{X}$ & & $\mathrm{X}$ & & $\mathrm{X}$ & $\mathrm{X}$ & $\mathrm{X}$ & $\mathrm{X}$ \\
\hline Wildlife Act & $\mathrm{X}$ & $\mathrm{X}$ & $\mathrm{R}$ & $\mathrm{R}$ & $\mathrm{R}$ & $\mathrm{R}$ & $\mathrm{X}$ & \\
\hline Sensitive ecosystems & $\mathrm{X}$ & $\mathrm{X}$ & $\mathrm{X}$ & $\mathrm{X}$ & $\mathrm{X}$ & $\mathrm{X}$ & $\mathrm{X}$ & $\mathrm{X}$ \\
\hline
\end{tabular}

L = Limit, $\mathrm{R}=$ Restrict, $\mathrm{E}=$ Encourage, $\mathrm{X}=$ Relax. 


\section{Implementation Hint}

Implementation of ICZM plan is a diplomatic phase, which requires involvement and participation of all stakeholders of the plan area. The stakeholders of the area should have thorough knowledge about the plan objectives and components. The ICZM plan should be a common implementation framework of all departments of Andaman and Nicobar Islands. The actions of the ICZM implementation activities should be managed and monitored by one among the existing departments involved in ICZM planning process and the regional task force can support the implementation activities. Task force should have the representatives of the various departments of the administrative block and the people representatives. Cross-sectoral coordination and consultation towards the developmental activities of the departments shall be encouraged prior to actions. To increase the fund resources to implement the developmental plans of the ICZM, central government ministries shall be approached. Local fund raising to share the development activities could encourage public participation in management and monitoring. Sector wise developmental plans may implement by case-by-case basis, based on the access and reception of the inhabited population. Exchange of experts/specialists within the department of different regions and between departments of Andaman are recommended for exchanging ideas to improve implementation techniques. External experts may be invited to get knowledge in special subjects case by case basis. Before implementing any developmental plan, the staff and peer group of Andaman and Nicobar islands shall be trained on ICZM plan implementation mechanism. Social institution strengthening and political will to implement the ICZM plan shall be achieved among the public.

\section{Conclusions}

ICZM plan is an essential long term tool offers directions to the short term developmental and management plans of the nation. ICZM plans have the capacity to identify the changes in the society and harmonize the institutional adjustment. This not only helps to meet the local requirements but also offers prerequisite for the international charters towards globalization and millennium development goals. The recommended strategies and decisions are based on the studies conducted between 2001 and 2003 and the decisions and strategies are suitable for short term. Assimilation of international programs, treaties, conventions, charters etc. in the ICZM plans, sectoral plans and local level plans provides advantageous for long term sustainable management goals.

The case study of ICZM methodology prepared for
Andaman Islands may be used for implementation in India and other coastal states of India. However, it is not essential to follow the methods and approached for ICZM plan preparation for Andaman Islands. ICZM plan preparation methods could be varied because coastal resources, issues, and management options are not uniform all over the world. ICZM Plan is mandatory for CRZ (Coastal Regulation Zone) Notification (2011), which is the notification under Environment Protection Act (1986), Government of India. Hence, ICZM plan is essential legal document for all development and protection plans of all coastal states of India. Methodology of case study of ICZM plan preparation methods of Andaman Islands and its outputs are widely accepted by the practitioners. Planning is a continuous process based on social and institutional changes, since human wants are not always been satisfied.

\section{Acknowledgements}

The authors wish to thank Prof. S. Ramachandran, Anna University, Chennai, India for conducting the ICZM Plan preparation project and for developing this manuscript. Further, the authors wish to thank Ministry of Environment and Forests, Government of India for the finance support to conduct the case study.

\section{REFERENCES}

[1] S. Jentoft and A. Buanes, "Challenges and Myths in Norwegian Coastal Zone Management,” Coastal Management, Vol. 33, No. 2, 2005, pp. 151-165. doi:10.1080/08920750590

[2] F. Veloso-Gomes, A. Barroco, A. R. Pereira, C. S. Reis, H. Calado, J. G. Ferreira, M. Da C. Freitas and M. Biscoito, "Basis for a National Strategy for Integrated Coastal Zone Management-In Portugal,” Journal of Coastal Conservation, Vol. 12, No. 1, 2008, pp. 3-9. doi:10.1007/s11852-008-0017-8

[3] S. Olsen, "Assessing Progress Toward the Goals of Coastal Management," Coastal Management, Vol. 30, No. 4, 2002, pp. 325-345. doi:10.1080/089207502900309

[4] R. Chuenpagdee and D. Pauly, "Improving the State of Coastal Areas in the Asia-Pacific Region,” Coastal Management, Vol. 32, No. 1, 2004, pp. 3-15. doi:10.1080/08920750490247445

[5] A. Meiner, "Integrated Maritime Policy for the European Union-Consolidating Coastal and Marine Information to Support Maritime Spatial Planning,” Journal of Coastal Conservation, Vol. 14, No. 1, 2004, pp. 1-11. doi:10.1007/s11852-009-0077-4

[6] G. Wescott, “The Theory and Practice of Coastal Area Planning: Linking Strategic Planning to Local Communities,” Coastal Management, Vol. 32, No. 1, 2004, pp. 95100. doi:10.1080/08920750490247535

[7] T. C. Matthew, F. J. Fodri and P. A. Hastings, “The Near 
shore Fish Assemblage of the Scripps Coastal Reserve, San Diego, California,” Coastal Management, Vol. 32, No. 4, 2004, pp. 341-351. doi:10.1080/08920750490487188

[8] T. O’Riordanand and H. Voisey, "The Political Economy of Sustainable Development,” Environmental Politics, Vol. 6, No. 1, 1997, pp. 1-23.

[9] M. D. A. Le Tissier, J. M. Hills, J. A. McGregor and M. Ireland, "A Training Framework for Understanding Conflict in the Coastal Zone,” Coastal Management, Vol. 32, No. 1, 2004, pp. 77-88. doi:10.1080/08920750490247517

[10] L. P. Hildebrand and J. Sorensen, "Draining and Swamp and Beating away the Alligators," Intercoast, University of Rhode Island, Vol. 39, 2001, pp. 20-21.

[11] A. T. M. S. Huda, "Interagency Collaboration for Integrated Coastal Zone Management: A Bangladesh Case Study,” Coastal Management, Vol. 32, No. 1, 2004, pp. 89-94. doi:10.1080/08920750490247526

[12] N. Harvey, B. D. Clarke and P. Carvalho, "The role of the Australian Coastcare program. In Community-Based Coastal Management: A Case Study from South Australia," Ocean and Coastal Management, Vol. 44, 2001, pp. 161-18. doi:10.1016/S0964-5691(01)00045-X

[13] W. K. de la Mare, "Marine Ecosystem-Based Management as a Hierarchical Control System," Marine Policy, Vol. 29, No. 1, 2005, pp. 57-68. doi:10.1016/j.marpol.2004.02.002

[14] H. L. Chibber, “Geology of Burma,” Macmillan \& Co., London, 1912, pp. 1-240

[15] K. Anon, “An Integrated Environmentally Sound Development Strategy for the Andman and Nicobar Islands," Planning Commission, New Delhi, pp. 1-56

[16] P. Davidar, "Some Guidelines for Prioritisation of Sites for the Network in the Andaman Islands," Workshop on "The Management of Protected Areas in the Andaman and Nicobar Islands", Port Blair, 9-11 July 2001, pp. 25-28.

[17] K. Anon, “State of Forest Report 1999,” Forest Survey of India, 1999, pp. 1-345.

[18] Andaman and Nicobar, Department of Forest and Environment Report, "Andaman and Nicobar Islands-Forests and Environment," Department of Environment and Forests, A \& N Administration, Port Blair, 2001, pp. 1-45.

[19] J. R. Turner, D. Vousden, R. Klaus, C. Satyanarayana, D. Fenner, K. Venkataraman, P. T. Rajan and N. V. SubbaRao, "Remote Sensing and Rapid Site Assessment Survey,” Report of Phase 1: April 2001, GOI/UNDP GEF, New Delhi, 2001, pp. 1-232.

[20] N. P. Balakrishnan, "Andaman Islands-Vegetation and Floristics,” In: C. J. Saldanha, Ed., Andaman, Nicobar and Lakshadweep, Oxford and IBH Publishing Co. Ltd., New Delhi, 1989, pp. 55-68

[21] C. J. Saldanha, "About Andaman and Nicobar-An Environmental Impact Assessment,” In: C. J. Saldanha, Ed., Andaman, Nicobar and Lakshadweep, Oxford and IBH Publishing Co. Ltd., New Delhi, 1989, pp 50-55.
[22] J. Tobey and R. Volk, "Learning Frontiers in the Practice of Integrated coastal Management," Coastal Management, Vol. 30, No. 4, 2002, pp. 285-298. doi:10.1080/089207502900228

[23] W. Salomons, R. K.Turner, L. D. de Lacerda and S. Ramachandran, Eds., "Perspectives on Integrated Coastal Zone Management,” Springer, Berlin, 1999, pp1-453.

[24] H. T. Yap, "Attempts at Integrated Coastal Management in a Developing Country," Marine Pollution Bulletin, Vol. 32, No. 8-9, 1996, pp. 588-591. doi:10.1016/0025-326X(96)00023-9

[25] Y. Wang, J. Tobey, G. Bonynge, J. Nugranad, V. Makota, A. Ngusaru and M. Traber, "Involving Geospatial Information in the Analysis of Land-Cover Change along the Tanzania Coast,” Coastal Management, Vol. 33, No. 1, 2005, pp. 87-99. doi:10.1080/08920750590883132

[26] W. Huang and B. Fu, "Remote Sensing for Coastal Area Management in China," Coastal Management, Vol. 30, No. 3, 2002, pp. 271-276. doi:10.1080/08920750290042200

[27] S. Jentoft and A. Buanes, "Challenges and Myths in Norwegian Coastal Zone Management," Coastal Management, Vol. 33, No. 2, 2005, pp. 151-165. doi: $10.1080 / 08920750590$

[28] J. P. Doody, "Information Required for Integrated Coastal Zone Management: Conclusions from the European Demonstration Programme," Coastal Management, Vol. 31, 2003, pp. 163-173. doi:10.1080/08920750390168381

[29] R. Chuenpagdee and D. Pauly, "Improving the State of Coastal Areas in the Asia-Pacific Region,” Coastal Management, Vol. 32, 2004, pp. 3-15. doi:10.1080/08920750490247445

[30] A. Hegarty, "Start with What the People Know: A Community Based Approach To Integrated Coastal Zone Management," Ocean \& Coastal Management, Vol. 36, No. 1-3, 1997, pp. 167-203. doi:10.1016/S0964-5691(97)00015-X

[31] C. F. Lenhart, "A Preliminary Review of NOAA's Community-Based Dam Removal and Fish Passage Projects,” Coastal Management, Vol. 31, No. 1, 2003, pp. 79-98. doi:10.1080/08920750390168318

[32] M. D. A. Le Tissier, M. Ireland, J. M. Hills, J. A. McGregor, R. Ramesh and S. Hazra, (Eds), “A Trainers' Manual for Integrated Coastal Management Capacity Development," The University of Newcastle upon Tyne, Newcastle upon Tyne, 2003, p. 187.

[33] C. Wood, B. Dipper and C. Jones, "Planning in the Coast and Marine," Journal of Environmental Planning and Management, Vol. 43, No. 1, 2000, pp. 23-47. doi:10.1080/09640560010757

[34] National Research Council, "The Science of Regional and Global Change: Putting Knowledge to Work,” Report of the NRC Committee on Global Change Research, National Academy Press, Washington, DC, 2001, pp. 1-523.

[35] D. Gibbs, J. Longhurst and C. Braithwaite, "Moving towards Sustainable Development? Integrating Economic Development and the Environment in Local Authorities,” 
Journal of Environmental Planning and Management, Vol. 39, No. 3, 1996, pp. 317-332.

doi:10.1080/09640569612444

[36] S. Sohng, "Participatory Research and Community Organizing,” Journal of Sociology and Social Welfare, Vol. 23, No. 4, 1996, pp. 77-97.

[37] R. D. Margerum and S. M. Born, "Integrated Environmental Management: Moving from Theory to Practice," Journal of Environmental Planning and Management,
Vol. 38, No. 3, 1995, pp. 42-48. doi:10.1080/09640569512922

[38] B. Shipman and T. Stojanovic, "Facts, Fictions, and Failures of Integrated Coastal Zone Management in Europe," Coastal Management, Vol. 35, No. 2, 2007, pp. 375-398. doi:10.1080/08920750601169659

[39] H. Calado, A. Quintela and J. Porteiro, "Integrated Coastal Zone Management Strategies on Small Islands," Journal of Coastal Research, Vol. 50, 2007, pp. 125-129. 